Original article

\title{
Conformational changes in natural biopolymers induced by electromagnetic field and cadmium ion exposure
}

\author{
Elena E. Tekutskaya
}

Kuban State University, Krasnodar, Russia

Received 24 November 2017, Revised 21 March 2019, Accepted 25 March 2019

(C) 2017, Tekutskaya E.E.

(C) 2017, Russian Open Medical Journal

\begin{abstract}
This research was aimed to study a combined influence of a low-intensity electromagnetic field (EMF) with 5-30 Hz frequency in presence of cadmium ions on structural changes in deoxyribonucleic acid (DNA) and human seralbumin (HSA). Special attention is paid to HSA, as it transports drug molecules and bound ligands. Changes that occur with DNA and HSA after exposure to EMF and cadmium ions are studied using the method of fluorescence spectroscopy.

Material and Methods - Aqueous solutions of HSA and DNA were the objects of this study. They were extracted from whole blood samples obtained from volunteers. The samples were processed for 10 minutes with EMF intensity at $24 \pm 4 \mathrm{~A} / \mathrm{m}$ and frequency increased stepwise by $2 \mathrm{~Hz}$.

Results - It was shown that after HSA and DNA were treated by EMF and cadmium ions, there was a significant increase in their fluorescence intensity when compared to control solutions, which reflects building of cadmium ions into DNA double helix as an intercalating agent and a disbalance in nucleic acid metabolism as well. When concentration of cadmium ions in aqueous HSA solution was as high as $10^{2}$ maximum acceptable concentration there was a softening of protein globules of HSA molecules within their native structure without complete protein denaturation.

Conclusion - A conclusion was made that combined exposure of studied factors on DNA and HSA molecules leads to a more significant change in structure of these biopolymers when compared to separate exposure of low-intensity EMF and cadmium ions.
\end{abstract}

Keywords: deoxyribonucleic acid, fluorescence spectroscopy, electromagnetic field, human seralbumin, cadmium.

Cite as Tekutskaya EE. Conformational changes in natural biopolymers induced by electromagnetic field and cadmium ion exposure. Russian Open Medical Journal 2019; 8: e0202.

Correspondence to Elena E. Tekutskaya. E-mail: tekytska@mail.ru, Phone: +79628560000

\section{Introduction}

Research into influence of low-frequency electromagnetic field (EMF) and heavy metal exposure on denaturation and conformational changes of deoxyribonucleic acid (DNA) and tryptophan-containing proteins is motivated mostly by the problem of screening for DNA-damaging factors. The study of influence of heavy metals exposure on structure of natural biopolymers, albumins in particular, is rationalized by need to discover new and effective methods to detect protein aggregation processes, which are activated by presence of heavy metals in environment [1, 2].

Serum albumin not only maintains an osmotic blood pressure and body's protein reserve, but also performs a significant function of transporting endogenic and exogenic substances [3]. While studying albino rats' blood serum using a fluorescencebased method, authors [4-7] have shown that an excess concentration of heavy metal ions in blood leads to blocking or allosteric change of albumin binding sites. In certain articles [4, 8] experimental data is discussed, which was obtained during research of low-frequency EMF exposure on the human serum albumin (HSA); the data was found using an analysis of intrinsic and induced fluorescence. The authors made a conclusion concerning the level of low-frequency EMF at which native conformation of human blood plasma proteins is preserved and, consequently, their functional properties as well.

Cadmium $\left(\mathrm{Cd}^{2+}\right)$ is one of the most dangerous toxic factors, having a deleterious impact on membranes, enzymes and genetic apparatus; it impairs nucleic acid and protein metabolism, has a tendency towards cumulation in heart, liver and kidney cells [1]. Cadmium ions which cumulate in mitochondria, lysosomes and nucleus, cause ultrastructural changes and interact with thiol groups of proteins thereby leading to metabolic deceleration and causing a hypoenergetic state with impairment of carbohydrate metabolism and hepatic glycogenesis [1]. It is known that local sewage pollution from mines and metallurgical plants, dye and mineral fertilizer factories, nickel-cadmium battery producing facilities etc., is a significant issue even after special purification because sewage still contains a substantial amount of cadmium salts. Therefore, $\mathrm{Cd}^{2+}$ intake and cumulation in human body is a pressing medical and ecological problem [9].

Research of EMF exposure on living systems gives significant attention to nucleic acid biopolymers. Many authors have observed the effects of EMF exposure on DNA, with EMF density being within range of fractures to hundreds of $\mathrm{mT}$. In one study [10] authors say about EMF mutagenicity. The magnetic field increases the extent of 
DNA damage $[9,11]$ and leads to defects in cell proliferation and apopotosis [12], as well as to altered gene expression [13]. Authors of one study [13] established that long-range charge transfer within DNA molecule and photon emission during molecular excitation of DNA are possible. A low-frequency EMF exposure is used to change the rate of some of important biochemical processes: repair of DNA elements with evident somatic mutations, generation of reactive oxygen species by neutrophils, change in cytokine levels etc. [3, 14-15]. A well-known manifestation of a cellular stress reaction is damage to biologically significant molecules, DNA first of all. In one article [14] an opinion is presented that changes in DNA hydration shell under the influence of specific low-frequency EMF exposure leads to the restoration of hydrogen bonds, bridging and DNA repair as a whole.

The aim of this research is to study how the combined exposure to low-intensity EMF with $5-30 \mathrm{~Hz}$ frequency and cadmium ions on human DNA and HSA structure using fluorescent spectroscopy, taking into account a significant role of HSA in the drug transport and mechanisms of ligand binding regulation, and to reveal possible denaturation and conformational changes of natural biopolymers.

\section{Material and Methods}

\section{Objects}

Aqueous solutions of DNA and HSA were the objects of this research. The DNA from the volunteers' blood samples (males, 2125 years old, non-smokers, $n=10$ ) was extracted by adsorption technique using "DNK-sorb-B» laboratory kits produced by «AmpliSens» (Moscow, Russia).

\section{DNA extraction from biological material}

Samples were processed using the following technique: blood was collected into $2.5 \mathrm{ml}$ plastic tubes containing ethylene diamine tetraacetate (EDTA) disodium salt with final concentration of $2.0 \mathrm{mg} / \mathrm{ml}$ as anticoagulant. The contents of the tube were mixed 23 times, centrifuged at $3000 \mathrm{rpm}$ for 20 minutes at room temperature $\left(18-25^{\circ} \mathrm{C}\right)$. Upper fraction was separated and transferred into another plastic tube. DNA extraction was done in a sterile laminar box «BAVp-01-Laminar» (Moscow, Russia) supplied with thermostat for Eppendorf tubes, vacuum aspirator for removal of supernatant fluid and vortex mixer. After taking a sample for further study, a lysing solution of guanidine was introduced into the test tubes. The samples extracted and prepared in the manner described above have been carefully resuspended using a vortex mixer in order to remove fragments of cell membranes and organelles. After that $25 \mu \mathrm{L}$ of a multipurpose sorbent were added into each tube. The procedure of resuspension was performed several times and was followed by centrifugation at 5,000 rpm. Then, supernatant fluid was removed by vacuum aspiration. After that, sorbent-containing samples were washed thoroughly multiple times, dried for $5-10$ minutes at $65^{\circ} \mathrm{C}$ temperature. Then, $50 \mu \mathrm{L}$ of TE buffer were put into the tubes to achieve DNA elution. The resulting liquid was resuspended by the vortex mixer and then dried for 5 minutes in the thermostat at $65^{\circ} \mathrm{C}$, then centrifuged at $12,000 \mathrm{rpm}$ for 1 minute. After all these procedures supernatant fluid contained purified DNA which was separated from sediments. The DNA concentration in final solution was evaluated by a spectrophotometric analysis using an extinction coefficient $E_{260 \mathrm{~nm}}=200$. The described method of extraction allows achieving DNA concentration up to $30 \mu \mathrm{g} / \mathrm{ml}$ in the final solution [16]. All further experiments were carried out using diluted aqueous solutions with DNA concentration of $2.5 \mu \mathrm{g} / \mathrm{ml}$.

HSA solution with $5 \mu \mathrm{M}$ concentration and cadmium acetate $\mathrm{Cd}^{2+}$ solutions with concentration from $0.5 \mu \mathrm{g} / \mathrm{ml}$ and above were also used in this study. To stabilize HSA solution the samples were stored at $4^{\circ} \mathrm{C}$ for a day or longer before measurements and adding of cadmium salts. Low concentration hydrochloric acid solution or potassium hydroxide solution were used to change the $\mathrm{pH}$ of a solvent.

\section{Treatment of samples by electromagnetic field}

Aqueous solutions of DNA and HSA were treated by EMF in a chemically clean and sterile plastic dish, with depth of irradiation being $2 \mathrm{~mm}$. In our experiments we used a device that we have described elsewhere [17, 18], designed for a computer-aided analysis of biological fluids in a variable magnetic field. Aqueous solutions of DNA and HAS were introduced into the module for measurement of physical characteristics of biological fluids. Temperature of the solution was controlled by a temperature sensor with $0.2^{\circ} \mathrm{C}$ precision and was maintained at $23^{\circ} \mathrm{C}$, initial magnetic field frequency was $1 \mathrm{~Hz}$, intensity was $24 \pm 4 \mathrm{~A} / \mathrm{m}$; the sample was treated for 10 minutes. Then the intensity of fluorescence of DNA and HSA aqueous solutions was registered. After that a microcontroller measured the frequency of the magnetic field with a $2 \mathrm{~Hz}$ step within the range of 1 to $30 \mathrm{~Hz}$. After each frequency measurement and sample treatment the intensity of fluorescence was registered and a $30 \mathrm{~s}$ pause was made.

\section{Registration of fluorescence of DNA and HSA aqueous solutions}

Evaluation of fluorescence was performed at room temperature $\left(22^{\circ} \mathrm{C}\right)$ using «Hitachi F-2700» (Japan) spectrofluorometer. Tryptophan fluorescence of HSA aqueous solutions was registered in the range of $270-500 \mathrm{~nm}$ at $\lambda_{\text {exct }}=295 \mathrm{~nm}$ excitation wavelength. Tryptophan fluorescence of DNA solutions was registered in the range of $220-900 \mathrm{~nm}$ at wavelength of $\lambda_{\text {exct }}=320 \mathrm{~nm}$.

\section{Statistical analysis}

Obtained data was analyzed using "Statistica 6.0" statistical package (StatSoft, USA). Hypothesis of normal (Gaussian) type of distribution for data on fluorescence intensity of DNA and serum albumin solutions was tested using a Shapiro-Wilk test, as well as by determining the ordinates of a normalized Gaussian distribution function according to the recommendations outlined in a paper [19]. Experimentally obtained data had normal type of distribution, which made it possible to use Student's test for statistical processing of the results with a significance level of 0.05 . Correlation analysis of the joint effect of EMF frequency and cadmium ions on the DNA fluorescence intensity was performed using Spearman correlation analysis [19].

\section{Results}

Nucleic acids, as well as tryptophan-containing proteins, belong to natural fluorophores which allows studying their condition in aqueous solutions using fluorescence spectroscopy. An optimal wavelength for DNA aqueous solution excitation found during the experiment was $320 \mathrm{~nm}$. In the fluorescence spectrum of DNA aqueous solutions at $\lambda_{\text {exct }}=320 \mathrm{~nm}$ there are two peaks of fluorescence intensity at $320 \pm 1$ $\mathrm{nm}$ and $640 \pm 5 \mathrm{~nm}$ respectively (Figure 1 ). 


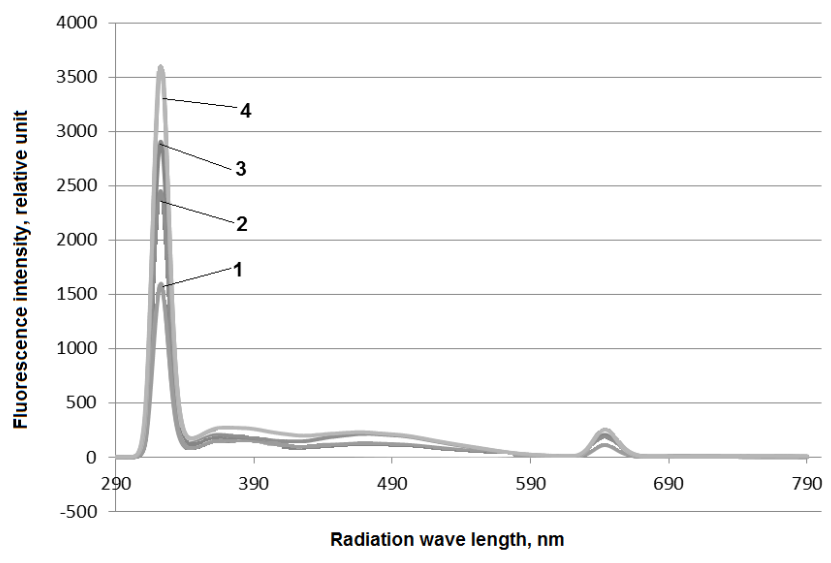

Figure 1. Fluorescence spectra of aqueous DNA solution with $2,5 \mu \mathrm{g} / \mathrm{ml}$ concentration after EMF exposure, Hz: 19 (1), 15 (2), 13 (3), 25 (4). 10 minutes exposure, $\lambda_{\text {exct }}=320 \mathrm{~nm}, \mathrm{t}=22^{\circ} \mathrm{C}$.

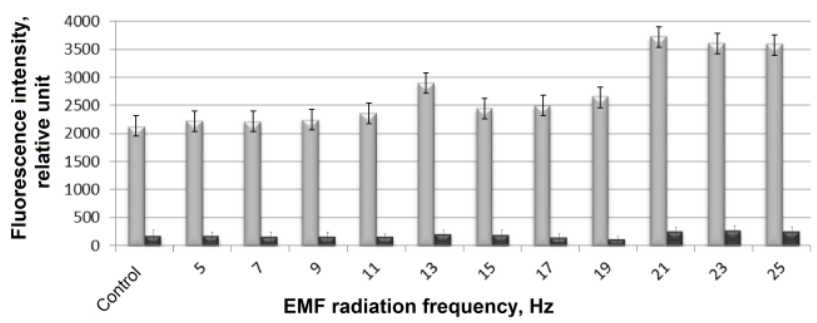

Figure 2. The effect EMF frequency on the fluorescence intensity of aqueous solutions of DNA.

The fluorescence intensities of aqueous solutions of $I_{\max 1}$ DNA (at $320 \mathrm{~nm}$ ) are gray columns and $I_{\max 2}$ (at $640 \mathrm{~nm}$ ) are black columns, studied for DNA solutions after their treatment with an electromagnetic field, having corresponding frequencies indicated along the $\mathrm{X}$-axis, from 5 to $30 \mathrm{~Hz}$. The EMF exposure time was 10 minutes for each sample, the fluorescence excitation wavelength was $320 \mathrm{~nm}$ at a temperature of $22^{\circ} \mathrm{C}$.

During EMF exposure of DNA aqueous solutions there was an insignificant increase of the first peak area at $13 \mathrm{~Hz}$ and $21-25 \mathrm{~Hz}$ EMF frequency when compared with controls (Figure 2). The area of the second peak changed little.

Addition of cadmium ions into aqueous solution of DNA above maximum acceptable concentration (MAC) leads to a staged increase in fluorescence intensity and to an increase of cadmium concentration (Figure 3); this reflects the absence of DNA denaturation process in which fluorescence would have subsided [6]. Cadmium MAC in whole blood is reported by certain sources $[16,20]$ to be $0.007 \mu \mathrm{g} / \mathrm{ml}$. Several plateaus are observed (Figure 3 ) on the curve illustrating an association between fluorescence intensity of DNA aqueous solution and $\mathrm{Cd}^{2+}$ concentration in the solution at the points corresponding to $\mathrm{Cd}^{2+} /$ DNA $=1: 5 ; 1: 2.5 ; 1: 1$. This demonstrates a discrete nature of changes in DNA structure associated with presence of cadmium ions in the solution. Possibly, cadmium ions build themselves into DNA double helix as an intercalating agent and zinc antagonist, which further leads to an impairment in nucleic acid metabolism, as it was described by some authors [1].

During the treatment of DNA solutions with EMF with $5-30 \mathrm{~Hz}$ frequency in presence of cadmium ions there was a more pronounced increase of fluorescence intensity, being up to 2-2.3 times more intensive (Figure 4). This confirms an assumption that cadmium ions build into the DNA double helix, which causes an increase of the intensity DNA molecule fluorophores glowing. Stabilization of DNA double helix by cadmium ions can be used in one of the branches of biotechnology: in nanotechnology of nucleic acids [21], as well as in production of molecular wires and novel biopolymer-based molecular devices [22]. A correlation analysis of the joint influence of EMF frequency and concentration of cadmium ions on DNA fluorescence intensity was performed by calculating the Spearman's rank correlation coefficient, which was 0.5 .

An intrinsic HSA fluorescence spectra were filmed with different amounts of cadmium in the solution at the physiological value of $\mathrm{pH} 7.4$ above the albumin isoelectric point ( $\mathrm{pl}=4.7)$ and with long excitation waves at $295 \mathrm{~nm}$. The fluorescence spectra are presented on Figure 5. It is evident that in cadmium concentrations in the solution lower than or equal to the HSA concentration, there is an insignificant decrease of the HSA fluorescence intensity, which is probably due to destabilization of a tertiary structure of protein, as the albumin globule is labile and sensitive even to weak influence [21].

\section{Discussion}

The first peak in the fluorescent spectrum of DNA aqueous solutions is related to chromophores in the DNA molecule, which absorb ultraviolet (UV) radiation, the conjugated $\pi$-bonds of nitrogenous bases [21]. The peak does not coincide with the maximum of guanine fluorescent intensity, as some authors have noted [23]. Excitation of DNA aqueous solution by UV-radiation with a $320 \mathrm{~nm}$ wavelength led to an observed appearance of an additional fluorescence band, along with the band described above, which had a long-wave shift with $640 \mathrm{~nm}$ wavelength. It is possible that this fluorescence band appeared as a result of DNA bases oxidation by free radicals. In one article [6] authors associate the fluorescence spectrum peak with $635 \mathrm{~nm}$ maximum with the appearance of singlet oxygen in the solution. It is reported that peaks in the 535, 635 and $1270 \mathrm{~nm}$ wavelengths confirm that there is singlet oxygen in the studied solution, which emits photons of light during the transition into a basic triplet state. This conforms with the opinion stated in some papers [14, 15] in which it is said that one of the reasons for a changed chemiluminescence of DNA aqueous solutions under the lowfrequency EMF influence could be the production of reactive oxygen species in water. In one article [21] it is said about doubleand single-stranded breaks in DNA solutions which occur under the influence of peroxide radicals and low-frequency EMF exposure [22]. Thus, combined exposure of DNA molecules to EMF and cadmium ions may lead both to breaks in double helix caused by reactive oxygen species and incorporation of cadmium ions into non-damaged DNA double helix.

A native HSA molecule in aqueous solution has its own intrinsic fluorescence caused by an amino acid residue of tryptophan (Trp214) which is located at binding site I [7]. Binding site I markers are warfarin, iodipamide, phenylbutazone, azapropazone, bilirubin [7]. Because of the ligand binding their solubility in blood plasma increases, while their toxicity decreases and bound molecules get protected from enzymatic and oxidative degradation. HSA-ligand binding process significantly contributes to drug pharmacokinetics, influencing drug distribution and elimination. 


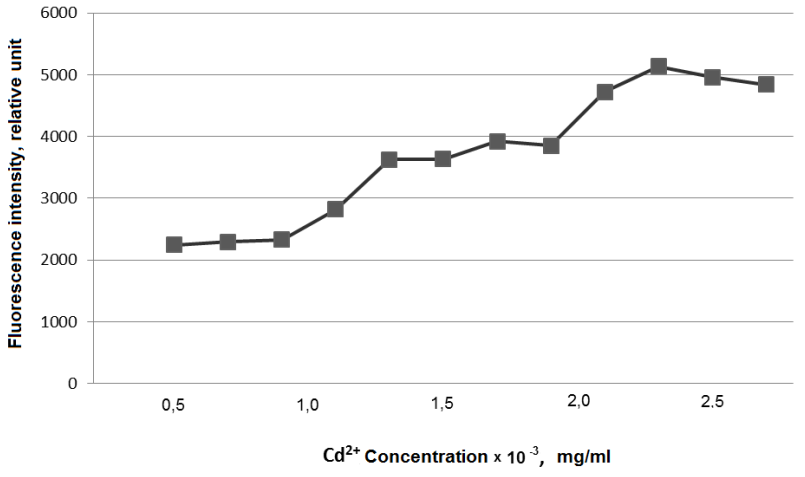

Figure 3. Association of fluorescence intensity of aqueous DNA solution $(2.5 \mu \mathrm{g} / \mathrm{ml})$ and $\mathrm{Cd}^{2+}$ concentration in the solution. $\lambda_{\text {exct }}=320 \mathrm{~nm}, \mathrm{t}=22^{\circ} \mathrm{C}$.

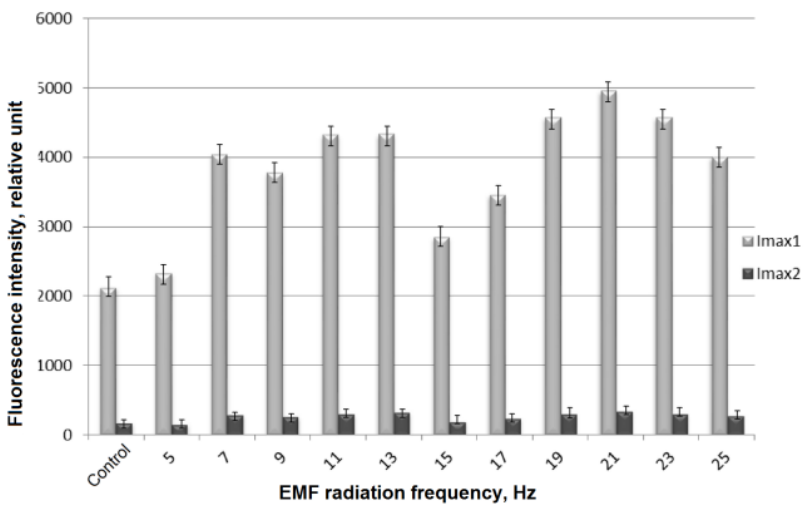

Figure 4. The combined effect of electromagnetic field and cadmium ions on the intensity of DNA aqueous solutions.

Fluorescence intensity (Imax1) - gray columns and (Imax2) - black columns of an aqueous solution of DNA $(2.5 \mu \mathrm{g} / \mathrm{ml})$ with cadmium ions (II) with a concentration of $0.5 \mu \mathrm{g} / \mathrm{ml}$ was measured after treatment with electromagnetic field having a corresponding frequency of 5 to $30 \mathrm{~Hz}$. The exposure time was 10 minutes, the wavelength of fluorescence excitation was $320 \mathrm{~nm}$ at a temperature of $22^{\circ} \mathrm{C}$.

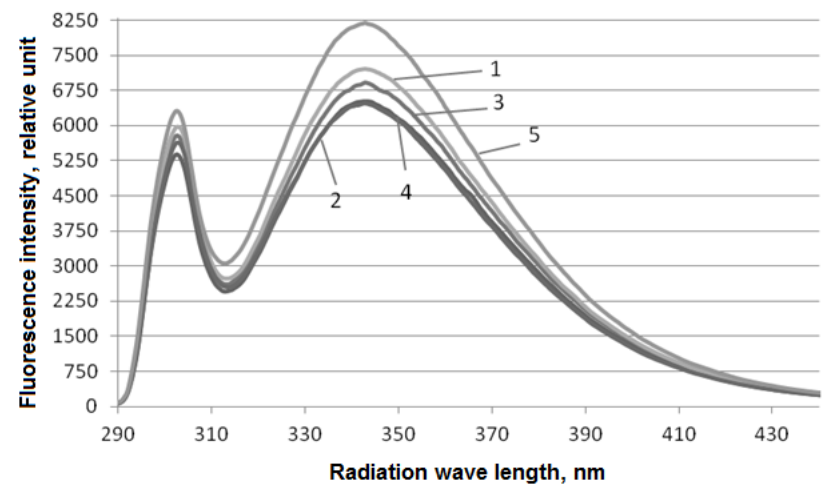

Figure 5. Intrinsic fluorescence spectra of human seralbumin $(5 \mu \mathrm{M})$ in relation with $\mathrm{Cd}^{2+}$ concentration in aqueous solution $(\mathrm{mg} / \mathrm{ml})$ : $0(1)$, 0.01 (2), 0.05 (3), 0.25 (4), 0.5 (5). $\lambda_{\text {exct }}=295 \mathrm{~nm}, \mathrm{t}=22^{\circ} \mathrm{C}, \mathrm{pH} 7.4$.

HSA fluorescence is observed at extinction wavelength from 280 to $295 \mathrm{~nm}$ and at emission wavelength of $350 \pm 3 \mathrm{~nm}[2,8,20]$. With $\mathrm{pH}$ value between 6.0 and 8.0 conformational changes of albumin are accompanied by changes in the milieu of amino acid residues of tryptophan, tyrosine, histidine and by an N-B-transition of the molecule which leads to an increase in availability of $\mathrm{N}$-form imidazole residues, while the size of the globule remains unchanged [4]. In this case $\mathrm{Cd}^{2+}$ cations can interact with available imidazole residues in HSA molecule and therefore decrease the ability of ligands to bind with site I. The decrease of fluorescence intensity of HSA (Figure 5) reflects the partial blocking of binding site I where fluorophore Trp-214 is situated.

Significant structural changes of albumin molecules in solutions with cadmium concentration comparable to HSA concentration are probably hindered by a system of inaccessible SS-bonds spaced throughout the length of all the polypeptide chain [7], and this preserves albumin molecule from denaturation. Flexibility of HSA molecule, its extreme conformational lability and ability to fold/unfold serve as basis for allosteric influence of cadmium ions on the condition of binding site $\mathrm{I}$, and on the ligand and drug binding with albumin as a whole.

Therefore, a combined influence of cadmium cations and lowfrequency EMF on the characteristics of fluorophores in DNA and HSA molecules leads to an intensification of structural changes in DNA and HSA.

\section{Conclusion}

Based on the experimental findings we may conclude that under combined influence of cadmium cations and low-frequency EMF on DNA molecule two simultaneous processes happen: DNA helix breaks happen under the influence of reactive oxygen species and cadmium ions build themselves into non-damaged DNA double helix, which leads to an increase in cadmium toxicity and a disbalance in nucleic acid metabolism.

When the concentration of cadmium cations in HSA solutions increases to $10^{2}$ MAC conformational changes in HSA within its native structure are observed; in particular, there are changes in condition of binding site I and albumin ability to bind ligands and drug molecules.

\section{Acknowledgements}

The study was organized with financial support from the Russian Foundation for Basic Research p_a № 16-42-230187.

\section{Ethical approval}

Laboratory part of the study was planned and performed in accordance with ethical practices set out in the Declaration of Helsinki of 1975, amended in 1983.

Conflict of interests: authors have no conflict of interest to disclose.

\section{References}

1. Avtsyn AP, Zhavoronkov AA, Rish MA, Strochkova LS. Human microelementosis. Moscow: Medicina, 1991; 495 p. Russian. https://search.rsl.ru/ru/record/01001582230.

2. Tekuckaja EE, Chebochinov KV, Prokofiev AS. Action of electromagnetic field of low frequency on plasma of blood. International Research Journal 2016; (2(44)): 38-40. Russian. https://doi.org/10.18454/IRJ.2016.44.103.

3. Phillips JL, Singh NP, Lai H. Electromagnetic fields and DNA damage. Pathophysiology 2009; 16(2-3): 79-88. https://doi.org/10.1016/j.pathophys.2008.11.005.

4. Kuz'micheva LV, Lopatnikova EG, Pugacheva IA. The study of the albumin functions by the fluorescent method in heavy metals. 
Advances in Current Natural Sciences 2009; (11): 74. Russian. https://elibrary.ru/item.asp?id=12931552.

5. Banerjee A, Lahiri S. Albumin metal interaction: a multielemental radiotraced study. I Radioanal Nucl Chem 2009; 279(3): 733-741. https://doi.org/10.1007/s10967-008-7372-7.

6. Vlasova IM, Vlasov AA, Saletskii AM. Complexation of serum albumins and triton X-100: Quenching of tryptophan fluorescence and analysis of the rotational diffusion of complexes. Russian Journal of Physical Chemistry A 2016; 90(7): 1479-1483. Russian. https://doi.org/10.7868/S0044453716070335.

7. Ghuman J, Zunszain PA, Petitpas I, Bhattacharya AA, Otagiri M, Curry S. Structural basis of the drug-binding specificity of human serum albumin. J Mol Biol 2005; 353(1): 38-52. https://doi.org/10.1016/i.jmb.2005.07.075.

8. Tekutskaya EE, Gusaruk LR. Monitoring of congenital maxillofacial developmental anomalies in conditions of adverse effect of environmental factors. Human Ecology (Russian Federation) 2013; (5): 18-23. Russian. https://elibrary.ru/item.asp?id=19021309.

9. Saito $K$, Suzuki $H$, Suzuki K. Teratogenic effects of static magnetic fields on mouse fetuses. Reprod Toxicol 2006; 22(1): 118-124. https://doi.org/10.1016/j.reprotox.2005.08.003.

10. Potenza L., Cucchiarini L., Piatti E, Angelini U, Dachà M.. Effects of extremely low-frequency magnetic fields exposure on different DNAs. Bioelectromagnetics 2004; 352-355. https://doi.org/10.1002/bem.10206.

11. Yokus B. Cakir DU, Akdag MZ, Sert C, Mete N. Oxidative DNA damage in rats exposed to extremely low frequency electromagnetic fields. Free Radic Res 2005; 39(3): 317-323. https://doi.org/10.1080/10715760500043603.

12. Ghibelli L, Cerella C, Cordisco S, Clavarino G, Marazzi S, De Nicola M, et al. NMR exposure sensitizes tumor cells to apoptosis. Apoptosis 2006; 11(3): 359-365. https://doi.org/10.1007/s10495-006-4001-1.

13. Hirrai $\mathrm{T}$, Yoneda $\mathrm{Y}$. Transcriptional regulation of neuronal genes and its effect on neural functions: Gene expression in response to static magnetism in cultured rat hippocampal neurons. J Pharmacol Sci 2005; 98(3): 219-224. https://www.ncbi.nlm.nih.gov/pubmed/16020920.

14. Tekutskaya EE, Barishev MG, Ilchenko GP. The effect of a low frequency electromagnetic field on DNA molecules in aqueous solutions. Biophysics 2015; 60(6): 913-916. https://doi.org/10.1134/S000635091506024X.

15. II'chenko GP, Baryshev MG, Tekutskaya EE, Shelistov VS, Nikitin AV. A Device for searching for optimal alternating magnetic field parameters for the treatment of biological objects. Meas Tech 2017; 60(6): 632637. https://doi.org/10.1007/s11018-017-1247-7.

16. Encyclopedical dictionary of medical terminology. Volume III. Moscow, USSR: Sovet Encyclopedia, 1984; 512 p. Russian. http://www.encyclopedia.ru/cat/books/book/52974.

17. Baryshev MG, II'chenko GP, Tekutsaya EE, Lomakina LV. Device for the computer-aided study of biological fluids in a variable magnetic field. Patent of the RF №163735, 10 Aug 2016. Russian.

18. Lomakina LV, Baryshev MG, Tekutsaya EE. Method of the study of biological fluids in a variable magnetic field. Patent of the RF №2621157, 31 May 2017. Russian.

19. Gerasimov AN. Medical statistics: a textbook for students of medical universities. Moscow: Medical News Agency, 2007; 475 p. Russian.

20. International Programme on Chemical Safety (IPCS). Environmental Health Criteria for Cadmium. WHO, 1992. http://www.inchem.org/documents/ehc/ehc/ehc134.htm.

21. Evdokimov luM, Salianov VI, Kats El, Skuridin SG. Structural nucleic acid nanotechnology: liquid-crystalline approach. Biophysics 2013; 58(6): 9871004. Russian. https://www.ncbi.nlm.nih.gov/pubmed/25486757.

22. Lakhno VD, Sultanov VB. Hopping and superexchange mechanisms of charge transfer in DNA. Biophysics 2003; 48(5): 797-801. Russian. https://elibrary.ru/item.asp?id=17291311.
23. Chernitskii E. A., Slobozhanina E. I. Spectral luminescent analysis in medicine. Minsk: Science and Technology, 1989; 141 p. Russian. https://search.rsl.ru/ru/record/01001461410.

\section{Authors:}

Elena E. Tekutskaya - PhD, Associate Professor, Department of Radiophysics and Nanotechnologies, Kuban State University, Krasnodar, Russia. https://orcid.org/0000-0003-1689-8815. 